CZASOPISMO INŻYNIERII LĄDOWEJ, ŚRODOWISKA I ARCHITEKTURY

JOURNAL OF CIVIL ENGINEERING, ENVIRONMENT AND ARCHITECTURE

JCEEA, t. XXXIV, z. 64 (3/II/17), lipiec-wrzesień 2017, s. 115-124, DOI:10.7862/rb.2017.158

Andrzej KADLUCZKA ${ }^{1}$

\title{
ZAPOMNIANE DZIEDZICTWO ARCHITEKTONICZNE PRZESZŁOŚCI I NOWATORSKIE METODY JEGO RESTYTUCJI W STRUKTURZE MIASTA PRZYSZŁOŚCI
}

\begin{abstract}
Artykuł omawia zagadnienia harmonijnej koegzystencji dziedzictwa architektonicznego z przeszłości z nowoczesna struktura miasta współczesnego i miasta przyszłości. Dziedzictwo to, co potwierdzają doświadczenia wielu wysoko rozwiniętych krajów europejskich jest bezcennym kapitałem dla projektów zrównoważonego rozwoju społeczno-gospodarczego. Rozpoznanie dziedzictwa na obszarach o wysokim stopniu urbanizacji i atrakcyjna muzealizacja stanowisk archeologicznych w przestrzeni miasta może stworzyć nową, synergiczną wartość podnoszącą jakość przestrzeni egzystencjonalnej człowieka. Nowa dziedzina: archeologia spoteczna jest projektem na rzecz dziedzictwa, w którym „czysta nauka” jest narzędziem w kreowaniu wspólnych celów o znaczeniu społeczno-kulturalnym i gospodarczym opartych na integracji ,,wartości archeologicznych” z interesem lokalnych społeczności i miejscowych sektorów wytwórczych.
\end{abstract}

Słowa kluczowe: miasto, urbanizacja, miasto przyszłości, dziedzictwo architektoniczne, ochrona dziedzictwa kulturowego

\section{Wprowadzenie}

Miasto jest najstarszą, znaną od tysięcy lat formą zbiorowego osadnictwa, która stwarzała najlepsze warunki dla szerokiej aktywności jednostki i grup społecznych. Oznacza to, że ta forma musiała podlegać procesom stałej transformacji, nadążającej za potrzebami i nowymi możliwościami wynikającymi z postępu i rozwoju społeczeństwa.

Badając rozwój cywilizacji zurbanizowanych Lewis Mumford, wybitny amerykański socjolog, historyk i filozof, uważał miasto średniowieczne jako doświadczenie poprzedzające koncepcję „,miasta idealnego” będącego kontrpro-

${ }^{1}$ Andrzej Kadłuczka, Politechnika Krakowska, Instytut Historii Architektury i Konserwacji Zabytków ul. Kanonicza 1, 31-002 Kraków; tel.: 12628 2450; e-mail: andrzej.kadluczka@gmail.com 
pozycją do antycznych, a zwłaszcza rzymskich megalopolis, które nie przetrwały próby czasu² [4].

Jest rzeczą interesującą, że miasto średniowieczne, planowane i budowane w oparciu o przywileje i statuty wydawane lub ustalane przez podmiot lokujący, często wykorzystywały relikty, lub ruiny miast mających metrykę starożytną, lub w miejscu wcześniejszych założeń osadniczych.

\section{Prawo ciągłości w urbanistyce}

Upadek cesarstwa rzymskiego oraz okres wędrówek ludów zahamował przejściowo urbanizację Europy, ale już we wczesnym średniowieczu rozwój miast stał się istotnym czynnikiem polityczno-gospodarczym i choć budowane one były na nowych zasadach organizacyjnych i w oparciu o zmodyfikowane prawodawstwo rzymskie, to najczęściej wykorzystywały pozostałości rzymskich castrów, które wchłaniane były jako centra nowych struktur urbanistycznych.

Fenomenem jest ciągłość lokalizacyjna, która była wynikiem znakomitego rozpoznania przez Rzymian warunków przyrodniczo-topograficznych i obronnych, gdzie wznosili oni swoje miasta, a wykorzystywanie tych miejsc i pozostałości rzymskich tworzyło nową tradycję, która miała znaczenie polityczne budując prestiż nowych rodów królewskich i książęcych jako spadkobierców cesarstwa zachodnio rzymskiego. Inną genezę miała budowa nowych miast inicjowana przez rozwijające się struktury kościoła rzymskiego w postaci miast biskupich, kolegiackich, czy klasztornych, które obok funkcjonowania jako zaplecze $i$ argument dla prowadzonej misji religijnej, miały także cele gospodarcze.

Tadeusz Tołwiński uważał, że średniowieczne miasto europejskie w wyniku wydarzeń historycznych odrodziło się jako wielkie ,dzieło ręki i ducha ludzkiego ... na ruinach państwa rzymskiego"3 i choć „,nowi ich mieszkańcy, praojcowie dzisiejszej kultury miejskiej, korzystając z dawnego uktadu ulic, z watów, bram i murów obronnych - a gdzie się dało - $i$ z dawnych budowli mieszkalnych i z gmachów publicznych" " stworzyli nowe plany i wizję pozwalającą na dynamiczny rozwój tak zamierzonego miasta w czasach nowożytnych i współczesnych, to jego centrum najczęściej opierało się na ,podstawowym szkielecie ulic rzymskich"5 [7].

Tak było właśnie w przypadku wielu miast europejskich, dziś wielkich metropolii administracyjnych i centrów gospodarczych, których dziedzictwo architektoniczno-urbanistyczne tworzy skomplikowaną strukturę stratygraficzną,

\footnotetext{
${ }^{2}$ L. Mumford, The City in History, its origins, its transformations and its prospects, Harcourt Inc. Ed., San Diego 1961

${ }^{3}$ T. Tołwiński, Urbanistyka, tom I budowa miasta w przeszłości, Wyd. Trzaska, Evert i Michalski, Warszawa 1948, s. 60

${ }^{4}$ Ibidem, s. 61

${ }^{5}$ Ibidem, s. 61
} 
coraz bardziej obecną w projektowaniu miasta przyszłości. Lista tych miast jest długa, ale warto wymienić choćby kilka o znaczeniu ponad regionalnym i stołecznym, jak: Neapol, Florencja Rzym, Paryż, Marsylia, Frankfurt n. Menem, Trewir, Kolonia, Saragossa, Tarragona, Wiedeń czy Budapeszt. Wszystkie one mają rzymską tradycję, która jest wyraźnie widoczna strukturze miasta współczesnego i można prognozować, że ta widoczność znacznie wzrośnie w przyszłości.

Pozwolę sobie w tym miejscu sięgnąć raz jeszcze do zacytowanego wcześniej polskiego „klasyka” urbanistyki Tadeusza Tołwińskiego, który w kontekście podstawowego dylematu współczesnej urbanistyki miejskiej - czytelnego wyraźnie w tytule konferencji „Dziedzictwo urbanistyczne w mieście przyszłości na przyktadzie potencjatów innowacji i rozwoju Rzeszowa oraz innych miast" nie miał wątpliwości, że poszukiwanie współczesnego „kształtu miasta pod względem jego konstrukcji i formy wymaga poznania miasta dawnego $z$ dwu powodów: $1^{\circ}$ - Miasto europejskie, a w szczególności miasto polskie XX wieku wyrasta na mniejszym lub większym pokładzie miasta dawnego i stanowi dalsze ogniwo $w$ ewolucji tworu urbanistycznego epok ubiegtych, $2^{o}$ - Tylko badanie historyczne sięgające do okresów powstawania miast w sposób planowy i harmonijny prowadzi do wykrycia tych czynników, które w różnych epokach stworzyty miasta niemal doskonate $w$ swej organizacji urbanistycznej i formie ${ }^{6}{ }^{6}$ ).

Zachęcony tym zaleceniem, chciałbym zwrócić uwagę na jeden z najistotniejszych - jak sądzę - elementów miasta jakim jest dziś tzw. przestrzeń publiczna, dawniej nazywana „rynkiem”.

To właśnie ten element jest kanwą kompozycji historycznego planu urbanistycznego, ale jest także obecny niezmiennie na każdym etapie rozwoju społecznego i urbanizacji jemu towarzyszącej. Czy to będzie antyczny Milet lub Timgad, słowiański Biskupin, średniowieczne miasto np. Kraków, idealne miasto renesansowe Palma Nova i jej rodzima zamojska edycja, jak też współczesne pionierskie rozwiązania w rodzaju Chandigar Le Corbusiera, czy Brasilia Costy i Niemeyera.

Rynek był i jest specyficzną formą funkcjonalno-przestrzenną miasta przestrzeniq społeczna - w której kumulują się różne rodzaje aktywności jednostki i zbiorowości: celebracje religijno-polityczno-obyczajowe, działalność gospodarcza i formy komunikacji społecznej w obszarach administracyjnym, sądowniczo-egzekucyjnym, naukowym i artystycznym. Rynek jest, jak widać specyficzną przestrzeniq spoteczna, w której sacrum przenika się z profanum ${ }^{7}$.

Przedstawiona tu w wielkim skrócie, a zarazem uproszczeniu historyczna interpretacja przestrzeni społecznej wyraźnie ukazuje człowieka jako jednostkę

\footnotetext{
${ }^{6}$ T. Tołwiński, op. cit.

${ }^{7}$ A. Kadłuczka, Przestrzeń publiczna $w$ historycznym mieście, a ochrona pamięci, tradycji $i$ tożsamości miejsca, w: Definiowanie przestrzeni architektonicznej, Czasopismo Politechniki Krakowskiej. Z.9-A/2006,
} 
lub zbiorowość w stanie permanentnej kolektywnej kreacji obrazu miasta i równoczesnej jego indywidualnej i różnorodnej percepcji ${ }^{8}$.

Ten obraz, który wg Kevina Lyncha [3] jest w obecnym nurcie badań istotnym elementem identyfikacji i interpretacji miasta ${ }^{9}$, u Aldo Rossiego [6] definiowany jest jako złożona $\mathrm{z}$ artefaktów architektura miasta ${ }^{10}$. Tak postrzegana architektura miasta podlegając stałej ewolucji jest zarazem formą trwającą niezmiennie w czasoprzestrzeni i stanowi potwierdzenie ,teorii ciagłości” Marcela Poete, dla którego trwałość miasta wynikała z trwałości jego budowli - fizycznie istniejących bytów - znaków przeszłości ${ }^{11}$, stałej topografii i kontynuacji zasady jego rozplanowania.

Aldo Rossi sam będąc szczególnie kreatywnym architektem pozostawał jednak w dystansie do "klasycznych” modernistów i sformułował tezę, że to ,funkcja podaża za forma". Ta teza jest dziś fundamentalnym paradygmatem w nowocześnie rozumianej teorii ochrony dziedzictwa architektonicznego przyjmującej, że to właśnie forma architektoniczna, fizycznie istniejąca, lub modelowana $\mathrm{w}$ naukowym procesie rekonstrukcji historycznej rzeczywistości ${ }^{12}$, wyznacza granice kreacji w skali urbanistycznej lub modernizacji w skali architektonicznej.

\section{Stratygrafia miasta}

Analizując zapomniane dziedzictwo architektoniczne przeszłości na obszarach zurbanizowanych, w badaniach niniejszych oparto się na wynikach głośnych odkryć archeologicznych jakie miały miejsce w Europie po 1945 roku. Wzięto pod uwagę zarówno skutki zniszczeń wojennych, które paradoksalnie znacznie wzbogaciły wiedzę o przeszłości miast, a także proces odbudowy i ich rozwoju, w toku którego nowe inwestycje poprzedzano szczegółowym archeologicznym rozpoznaniem terenu.

Zniszczenia wojenne powstałe w wyniku lotniczego bombardowania Londynu w 1940 roku, ujawniły na obszarze dzielnicy Barbicane relikty obozu warownego i miasta Londinium założonego w 47 roku n.e., które w projekcie pracowni architektonicznej Chamberlin, Powell\&Bon zostały wkomponowane w część mieszkalną (Estate) i publiczną (Centre). Jest to jeden z pierwszych powojennych projektów modernizacji historycznej dzielnicy, który wprowadził

\footnotetext{
${ }^{8}$ K. Lynch, Obraz miasta (The Image of the City), Wyd. Archivolta, 2011

${ }^{9}$ K. Lynch, op.cit.

${ }^{10}$ A. Rossi, The Architecture of the City, Oppositions Books

${ }^{11}$ H. G. Gadamer, Teoria, etyka, edukacja, Wydawnictwo Uniwersytetu Warszawskiego, 2008, por. także: Czytanie i interpretacja znaków przeszłości, czyli: dlaczego, co i jak mamy chronić? (preliminaria), w: Międzynarodowa Konferencja Konserwatorska Karta Krakowska 2000 - 10 lat później, praca zbiorowa pod red. naukową A. Kadłuczki, Monografia nr 400, seria Architektura, Wyd. PK Kraków 2011

12 J. Topolski, Teoria wiedzy historycznej, Wydawnictwo Poznańskie, 1983
} 
segregacje ruchu pieszego i kołowego, oraz integrował pozostałości rzymskich fortyfikacji i obiektów z modernizowaną przestrzenią wielkiej, stołecznej metropolii.

Współczesna Florencja, której historyczne centrum zostało mocno uszkodzone w nalotach alianckich w 1944 roku, jest miastem o korzeniach etruskich, ale w II wieku p.n.e. została zdobyta przez Rzymian, którzy zbudowali Florentię na typowej osnowie castrum. Jest ona dobrze czytelna nawet na dzisiejszym planie miasta, gdzie krzyżujące się ulice: via Strozzi i via Calimara to rzymskie Decumanus i Cardo z forum na ich skrzyżowaniu - dzisiejszym placem targowym Mercato Vecchio ${ }^{13}$.

Ale nie tylko rozplanowanie miasta świadczy o jego antycznej stratygrafii. Jeden z największych monumentów architektonicznych Florencji, średniowieczna siedziba władzy miejskiej - Palazzo Vecchio zaprojektowany przez Arnolfo di Cambio, zbudowany został w latach 1299-1301 na pozostałościach rzymskiego teatru. Relikty tego obiektu zostały odkryte jeszcze w 1876, ale dopiero w latach 2006-2010 zostały kompleksowo udokumentowane i zinterpretowane przez Riccardo Francovicha, pioniera włoskiej nowoczesnej archeologii. Dzięki jego badaniom wiemy, że obiekt powstał w I wieku n.e. w czasach późno rzymskiej prosperity Florentii i był użytkowany jeszcze w V wieku n.e. O jego skali świadczyć może 15 tysięczna widownia i zajmowany teren o wymiarach $35 \mathrm{x}$ 100 metrów. Dziś, znaczne i dobrze zachowane fragmenty teatru można oglądać w podziemiach Palazzo Vecchio i sąsiedniego Palazzo Gondii.

Stratygrafia historycznego miasta ma istotny wpływ na ostateczny kształt planowanych nowych inwestycji. Tak było w Trewirze, Kolonii i Saragossie, gdzie $\mathrm{w}$ toku realizacji pierwotna wersja programowo-przestrzenna musiała zostać zweryfikowana w wyniku badań archeologicznych, które ujawniły wcześniejsze warstwy kulturowe.

$\mathrm{W}$ Trewirze, mieście będącym jedną $\mathrm{z}$ ważnych siedzib rzymskiego cesarza, w latach 80. ubiegłego stulecia podjęto modernizację placu targowego Viehmarktplatz i budowę podziemnego parkingu. W trakcie wykonywania wykopów ukazały się relikty zapomnianych, ale dobrze zachowanych rzymskich term, które uniemożliwiły planowaną inwestycję w pełnym zakresie. Rzymskie ruiny zbadano i poddano zabiegom konserwatorskim, zaś nad nimi znany architekt niemiecki Oswald Mathias Ungers zaproponował nowy pawilon ekspozycyjny, chroniący nie tylko antyczne ruiny, ale także wzbogacający tę publiczną przestrzeń o szklaną, modernistyczną formę architektoniczną wewnątrz której pomieszczono kameralną salę koncertową, miejsce spotkań młodych, przestrzeń nowoczesnych wystaw i ekspozycji, a także funkcje gastronomiczne. Ten obiekt należy dziś obok bazyliki i Porta Negra do najliczniej odwiedzanych przez turystów miejsc w Trewirze.

${ }^{13}$ T. Wróbel, Zarys historii budowy miast, Ossolineum, 1971, s. 121 
Podobne problemy pojawiły się w procesie odbudowy niemieckiej Kolonii po dramatycznych zniszczeniach wojennych, kiedy zbombardowano historyczne średniowieczne centrum, zbudowane na szczątkach rzymskiego antycznego miasta.

Początki Kolonii jako rzymskiej osady wojskowej (castra Romana) sięgają połowy I wieku n.e. kiedy to urodzona tu cesarzowa Agrypina, żona Klaudiusza nadała jej status miasta. W 89 roku n.e. Kolonia została stolicą prowincji Galia ustanowioną przez Domicjana, dowódcę legionów Dolnej Germanii, rozwijając się dynamicznie i przeżywając okres prosperity ${ }^{14}$. O skali i standardzie rzymskiego miasta świadczy zbudowany najdłuższy w Cesarstwie Rzymskim akwedukt Eifel ${ }^{15}$ dostarczający przez blisko dwa wieki wodę dla 45 tysięcznej jego populacji.

Wieloletnie powojenne badania archeologiczne w centrum Kolonii doprowadziły rozpoznania skomplikowanej stratygrafii późno antycznego założenia samego miasta jak i jego pretorium, które stało się interesującym obiektem muzealnym. Relikty położone kilka metrów poniżej obecnego poziomu zostały wyeksponowane w podziemnej żelbetowej hali pod nowym gmachem ratusza miejskiego.

Szczególnie interesującym przypadkiem ilustrującym jak istotne dla współczesnej planistyki miejskiej mogą stać się relikty przeszłości jest Saragossa, której modelowa rewaloryzacja centrum przeprowadzona została przy mocnym wsparciu merytorycznym i ekonomicznym Unii Europejskiej, w ramach międzynarodowego konsorcjum APPEAR Project ${ }^{16}$, w oparciu o nową ideę publicznego dostępu do dziedzictwa (Public accses to archaeological sites in an urban context).

Odkryte relikty obiektów antycznych tworzą dziś tzw. CaesarAugusta Route, na trasie której zlokalizowane zostały cztery niezależne przestrzennie muzea, ale tworzące jednolitą ekspozycyjno-dydaktyczną całość. Są to muzea forum CaesarAugusta, portu rzecznego, term publicznych oraz teatru miejskiego ${ }^{17}$.

${ }^{14}$ Gerta Wolff, Roman-Germanic Cologne. A Guide to the Roman-Germanic Museum and City of Cologne, J.P. Bachem Verlag, Gologne Germany 2003

${ }^{15}$ Akwedukt Eifel zaopatrujący Kolonię w wodę w latach 80-250 n.e. miał 95 km długości, a wraz z odgałęzieniami $150 \mathrm{~km}$.

16 APPEAR Project (Accessibility Project Sustainable Preservation and Enhancement of Urban Subsolil Archaeological Remains) www.in-situ.be ,APPEAR promotes a global approach to accessibility projects from the planning stage to the exploatation stage. The research works is organised around two different but complemen-tary axes: urban governance and enhancement of the archaeological sites, considering their best integration within the city particularly on a sociocultural level. The main challenge consist in providing useful tools to make archaeological sites accessible and offering visitors scientific, educational and aesthetic quality while ensuring an optimal protection level"

${ }^{17}$ M. Beltran Lloris, J. Paz Peralta, J. Lasheras Corruchaga "El teatro de Caesaraugusta. Estado actual de las ex-cavationes" Museo de Zaragoza Boletin 4, Zaragoza 1985, str. 95-130; por.: A. Alvarez, A. Mostalic Carrillo MaC Aguarod Otal, M. Galve Izquierdo, F. Escudero Escuredo 
Zastosowana szeroko innowacyjna aranżacja przestrzeni muzealnych opiera się na integracji zachowanych elementów oryginalnych $\mathrm{z}$ imaginacją wspieraną współczesnymi środkami multimedialnymi, dostosowanymi do poszczególnych sekwencji tematycznych. Tematyka forum ogniskuje się na aspektach życia publicznego-politycznego i religijnego oraz administrowania miastem, to termy ukazują wykorzystanie ciepłych źródeł dla celów rekreacji, higieny i relaksu, port rzeczny ilustruje osiągnięcia techniczno-gospodarcze, zaś teatr głębię życia kulturalnego.

Szczególnie interesujący w sensie transformacji XIX wiecznej struktury miasta i jej modernizacji poprzez nowoczesną muzealizację wielkiego stanowiska archeologicznego jest przykład rzymskiego teatru antycznej Saragossy zbudowanego w I wieku n.e. przez Tyberiusza, a należącego do największych budowli tego typu wzniesionych w Hiszpanii $\left(7000 \mathrm{~m}^{2}\right.$ powierzchni oraz 6000 widzów). Muzeum Teatru powstałe w rezultacie odkryć archeologicznych w formie gigantycznej szklanej kopuły rozpiętej ponad częściowo tylko rekonstruowaną budowlą, ma za zadanie przy pomocy najnowszych technologii ukazać nie tylko historię budowli, służyć współczesnym potrzebom kulturalnym miasta.

\section{Społeczny wymiar przeszłości w mieście przyszłości}

Wiek XX przyniósł wielki przełom w myśli historyczno - konserwatorskiej, odrzucając XIX wieczny selektywny model ochrony zabytków, który zakładał podział na zabytki lepsze i gorsze, bardziej wartościowe i mniej wartościowe, te które należy konserwować już teraz, i te które można konserwować później, pozostawić je dla „przyszłych, lepszych czasów” i oczekując na bardziej doskonałe metody badawcze.

Istotą współczesnej ochrony dziedzictwa kulturowego jest wyraźna zmiana jego ontologicznego statusu, wyrażona nie tylko poprzez stałe rozszerzanie zakresu pojęciowego i tym samym obszaru ochrony: monument - zabytek - środowisko zabytkowe - dobro kultury - ekosystem kulturowy - dziedzictwo, ale także poprzez przeniesienie punktu ciężkości z wartości dziedzictwa na potrzeby społeczeństwa ${ }^{18}[5]$.

\footnotetext{
“Arqueologia urbana en Zaragoza 1984-1986", Zaragoza 1986, por.: A. Mostalic Carrillo, J.A. Perez Casas "La excavacion del foro de Caesaraugusta" La Plaza de La Seo. Zaragoza. Investigaciones Historico-Arqueologicas, Estudios de Arqueologica Urbana 2, Zaragoza 1989, str.: 81156.

18 J. Purchla, W strone ochrony dziedzictwa kulturowego w Polsce, Zarządzanie Publiczne, R. 2010, nr 2 (12), s. 69-82, (tekst zamieszczony w nin. wydawnictwie): „Do tej pory dziedzictwo miato specjalny status. Byto traktowane jako element przeszłości, który znalazt się w teraźniejszości, ale który w związku z tym wymaga odrębnego traktowania. Dzisiaj dziedzictwo należy do nas wszystkich, a dostęp do dziedzictwa to jedno z podstawowych praw człowieka. Dziedzictwo to przy tym nie tylko materialne dobra kultury, ale nasza pamięć i tożsamość. Tak znaczace przewartościowanie $w$ traktowaniu dziedzictwa prowadzi do zmiany podstawowych pytan, przed
} 
Tym samym standardy współczesne chronią dziedzictwo historyczne „totalnie”. Uważają je za dorobek społeczny i o znaczeniu nie tylko regionalnym, ale także globalnym. Uznają prawo społeczeństw do obcowania ze swoim dziedzictwem, do wszechstronnego badania tego dziedzictwa i jego obowiązkowego upowszechniania oraz udostępniania. Dotyczy to zwłaszcza obszarów zurbanizowanych i współczesnych miast podlegających intensywnej transformacji, gdzie w wizji miasta przyszłości istotnym czynnikiem staje się archeologia spoteczna ${ }^{19}$, a archeologia nie oznacza tylko wyrafinowanego warsztatu badawczego, lecz wraca do pierwotnej definicji terminu, gdzie: archaios - oznaczało rzecz dawną, starą, a logos - naukę i wiedzę o niej [1].

W tym zakresie znaczące osiągnięcia ma archeologia zachodnioeuropejska, która musiała znaleźć równowagę pomiędzy tradycyjną formułą rezerwatu, a otwartą na potrzeby społeczne muzealizacja stanowiska archeologicznego, badanego zwłaszcza na obszarach intensywnego rozwoju gospodarczego.

Archeologia społeczna jest w obszarze nauki zagadnieniem interdyscyplinarnym, ponieważ bada zjawiska i artefakty należące do przeszłości, ale musi uwzględniać zarazem mechanizmy wpływów na nie generowane przez szerokie spectrum podmiotów publicznych i prywatnych funkcjonujących w społeczeństwie obywatelskim. Musi umieć znaleźć aplikacyjny cel dla „czystej nauki”, której wyniki badań mogłyby być zastosowane w konkretnym sektorze: komunikacji, ekonomii i zarządzania, tożsamości kulturowej, czy polityki.

Innymi słowy: celem archeologii społecznej jest łączenie i programowanie badań archeologicznych z projektami aplikacyjnymi, ukierunkowanymi na osiągnięcie wspólnych celów o znaczeniu społeczno-kulturalnym i gospodarczym we współpracy z instytucjami odpowiedzialnymi (zarówno szczebla centralnego, regionalnego i lokalnego) za integrację ,wartości archeologicznych” z interesem lokalnych społeczności i miejscowych sektorów wytwórczych

\section{Konkluzje ${ }^{20}$}

Miasto przeszłości, teraźniejszości i przyszłości było, jest i będzie zawsze częścią przestrzeni egzystencjonalnej człowieka. Jej przekształcanie wymaga zachowania ładu przestrzennego [2].

Pojęcie ładu przestrzennego, choć znacznie węższe od pojęcia ,,przestrzennego zagospodarowania", odnosi się bezpośrednio do problematyki ochrony

którymi staja konserwatorzy. Dotychczasowe pytanie: Jak chronić zabytki, przybrało postać: Jak należy zabytki przeksztatcać? Cel, którym kiedyś była ochrona wartości zabytkowych, zmienia się w inny - wykorzystanie wartości zabytkowych”.

${ }^{19}$ Chodzi tu o nową dyscyplinę ,, archeologię publiczna lub społeczna” por.: Archeologia Publicca in Toscana, a cura di Guido Vannini, Firenze University Press, 2011

${ }^{20}$ Fragment tekstu zaczerpnięty z programowego artykułu z 2 kongresu Konserwatorów Polskich: A. Kadłuczka, Conservatio est continua creatio - czyli doktryna ochrony dziedzictwa jako komponentu przestrzeni egzystencjonalnej, w: Wiadomości Konserwatorskie nr 43/2015 
dziedzictwa kulturowego, jest bowiem formą kreacji takich relacji w przestrzeni egzystencjonalnej człowieka, które nowe konstruowanie i rekonstruowanie tej przestrzeni opierają na idei twórczej kontynuacji, kompozycyjnej harmonii estetycznej i zrównoważenia rozwoju społecznego.

Zasady twórczej kontynuacji i kompozycji estetycznej form przestrzennych miasta podał Juliusz Żórawski w swym fundamentalnym i nadal aktualnym dziele „O budowie formy architektonicznej”. Ten wybitny polski architekt modernista i filozof zdefiniował tam szczególne istotne dla „zrównoważonego" rozwoju cywilizacyjnego prawo dobrej kontynuacji w kontekście aktywnej i twórczej koncepcji ochrony zabytków architektury i urbanistyki, opartej na relacjach zachodzących pomiędzy formą przestrzenną i tłem, na którym jest ona postrzegana.

Historyczna faktografia transformacji zurbanizowanej przestrzeni egzystencjonalnej wyraźnie ukazuje człowieka jako jednostkę lub zbiorowość pozostające w stanie permanentnej kolektywnej kreacji obrazu miasta i równoczesnej jego indywidualnej i różnorodnej percepcji ${ }^{21}[3]$.

Jeden z wybitnych twórców i teoretyków, XX wieku - wspomniany wcześniej Aldo Rossi, obraz ten definiował jako zintegrowaną strukturę złożoną z historycznych artefaktów i współczesnej architektury miasta ${ }^{22}$ pozostającej w stałej ewolucji trwającej niezmiennie w czasoprzestrzeni i stanowiącej potwierdzenie „teorii ciągłości” Marcela Poete, dla którego trwałość miasta wynikała z trwałości jego budowli - fizycznie istniejących bytów - znaków przeszło$s^{\prime} c i^{23}$, oraz stałej topografii i kontynuacji zasady jego rozplanowania [6].

Aldo Rossi przyjmuje, że procesy dynamicznego rozwoju miasta prowadzą także do ewolucji jego monumentów, które są nie tylko zachowywane, ale mają także zapewniony rozwój i kontynuację. Przeciwstawia się on tzw. „kontekstualnej ochronie", która wg niego może stać się przyczyną zahamowania rozwoju miasta.

Tak zwana kontekstualna ochrona ma taki zwiazek z miastem jak zabalsamowane ciało świętego z historycznym wizerunkiem jego postaci ${ }^{24}$.

W ochronie dziedzictwa kulturowego integrowanego z przestrzenią egzystencjonalną człowieka niezbędna jest stała rozbudowa wiedzy i doskonalenie umiejętności, czyli ciągłe poszukiwanie i kreowanie nowych narzędzi, technik i technologii pozwalających eliminować lub ograniczać procesy destrukcyjne,

${ }^{21}$ K. Lynch, Obraz miasta (The Image of the City), Wyd. Archivolta, 2011

${ }^{22}$ A. Rossi, The Architecture of the City, Oppositions Books, The MIT Press, Cambridge, Massachusetts, London 1997

${ }^{23}$ H.G. Gadamer, Teoria, etyka, edukacja, Wydawnictwo Uniwersytetu Warszawskiego, 2008; por. także: A. Kadłuczka, Czytanie i interpretacja znaków przeszłości, czyli: dlaczego, co i jak mamy chronić? (preliminaria), w: Międzynarodowa Konferencja Konserwatorska Karta Krakowska 2000 - 10 lat później, praca zbiorowa pod red. naukową A. Kadłuczki, Monografia nr 400, seria Architektura, Wyd. PK, Kraków 2011.

${ }^{24}$ Ibidem 
a także coraz bardziej precyzyjnie dokumentować i interpretować różnorodną substancję składającą się na dziedzictwo.

\section{Literatura}

[1] Archeologia Publicca in Toscana, a cura di Guido Vannini, Firenze University Press, 2011

[2] Kadłuczka A., Conservatio est continua creatio - czyli doktryna ochrony dziedzictwa jako komponentu przestrzeni egzystencjonalnej, w: Wiadomości Konserwatorskie nr 43/2015

[3] Lynch K., Obraz miasta (The Image of the City), Wyd. Archivolta, 2011

[4] Mumford L., The City in History, its origins, its transformations and its prospects, Harcourt Inc. Ed., San Diego 1961

[5] Purchla J., W stronę ochrony dziedzictwa kulturowego w Polsce, Zarządzanie Publiczne, R. 2010, nr 2 (12),

[6] Rossi A., The Architecture of the City, Oppositions Books, The MIT Press, Cambridge, Massachusetts, London 1997

[7] Tołwiński T., Urbanistyka, tom I budowa miasta w przesztości, Wyd. Trzaska, Evert i Michalski, Warszawa 1948, s. 60

\section{HIDDEN ARCHITECTURAL HERITAGE OF THE PAST AND INNOVATIVE METHODS ITS RESTITUTION IN THE STRUCTURE OF THE FUTURE CITY}

\section{S u m m a r y}

The article discusses the issues of the harmonious coexistence of the architectural heritage of the past with the modern structure of the modern city and the city of the future. Heritage is what confirms the experience of many highly developed European countries is priceless capital for projects of sustainable socio-economic development. Recognition of heritage in highly urbanized areas and the attractive metallization of archaeological sites in urban space can create a new, synergistic value enhancing the quality of human existential space. A new field: public archeology is a heritage project where "pure science" is instrumental in creating common goals of socio-cultural and economic importance based on the integration of "archaeological values" with the interest of local communities and local manufacturing industries.

Keywords: city, urbanization, city of the future, architectural heritage, protection of cultural heritage 